\title{
Genetic analysis of pathogen-specific clinical mastitis in Norwegian Red cows
}

\author{
K. Haugaard, ${ }^{1}{ }^{1}$ B. Heringstad, ${ }^{\star} \dagger$ and A. C. Whistł \\ *Department of Animal and Aquacultural Sciences, Norwegian University of Life Sciences, PO Box 5003, N-1432 Ås, Norway \\ †GENO Breeding and A. I. Association, PO Box 5003, N-1432 Ås, Norway \\ $\ddagger$ Norwegian School of Veterinary Science, PO Box 8146 Dep, N-0033 Oslo, Norway
}

\section{ABSTRACT}

The objective of this study was to estimate heritabilities and genetic correlations for pathogen-specific clinical mastitis (CM) in Norwegian Red cows. In Norway, breeding values for mastitis are predicted based on records of veterinary treatments of clinical mastitis. Bacteriological milk sample results from the mastitis laboratories have been recorded routinely into the Norwegian Dairy Herd Recording System since 2000 , but have so far not been used in genetic analyses. This additional source of data may provide valuable information on pathogen-specific CM. Records from 234,088 first-lactation Norwegian Red cows, daughters of 1,656 sires, were used for genetic analyses of unspecific, Staphylococcus aureus, Streptococcus dysgalactiae, and Escherichia coli CM. The $4 \mathrm{CM}$ traits were defined as binary and scored as 1 if the cow had at least 1 case of the CM in question and 0 otherwise. A Bayesian approach using Gibbs sampling was applied, and a multivariate threshold liability model was used for the analyses. The posterior mean $(\mathrm{SD} \leq 0.01)$ of the heritabilities were 0.06 for liability of unspecific CM, 0.04 for Staph. aureus CM, 0.02 for Strep. dysgalactiae CM, and 0.03 for E. coli CM. The posterior mean (SD) of the genetic correlations were all high, ranging from 0.75 $(0.14)$ to $0.87(0.07)$. The highest genetic correlation was found between unspecific CM and Strep. dysgalactiae $\mathrm{CM}$, whereas the lowest was found for E. coli CM and Staph. aureus CM. Genetic correlations lower than 1 indicate that mastitis caused by different pathogens can be considered as partly different traits. In spite of high rank correlations (0.95-0.98), some re-ranking of sires was observed.

Key words: clinical mastitis, dairy cattle, genetic correlation, pathogen specific

Received May 10, 2011.

Accepted November 11, 2011

${ }^{1}$ Corresponding author: katrine.haugaard@umb.no

\section{INTRODUCTION}

Mastitis is the most frequent and costly disease in dairy cows worldwide, and can be caused by several different pathogens. Much research has been done on pathogen-specific mastitis with regard to immunology (e.g., Bannerman et al., 2004), pathogenesis (e.g., Calvinho et al., 1998), management and treatment (e.g., Barkema et al., 2006; Reksen et al., 2006; Piepers et al., 2011), and effect on milk production traits (e.g., Gröhn et al., 2004), but so far few genetic studies have been published. Weller et al. (1992) studied the incidence of bacterial udder infection and reported heritabilities of 0.05 and 0.03 from threshold and linear models, respectively. Nash et al. (2000) estimated heritabilities for clinical mastitis (CM) caused by different pathogen groups, ranging from 0.03 for CNS to 0.25 for streptococci other than Streptococcus agalactiae. Schafberg et al. (2006) reported heritabilities of 0.09 and 0.07 for IMI caused by CNS and Staphylococcus aureus, respectively. In a Dutch study, de Haas et al. (2002) estimated heritabilities for specific mastitis pathogens, ranging from 0.02 (streptococci other than Strep. agalactiae and Streptococcus uberis) to 0.10 (CNS) using logit threshold models. Sørensen et al. (2009) used a probit threshold model to estimate heritabilities for both single pathogens and for different groups of pathogens (gram-positive, gram-negative, contagious, and environmental) in Danish Holstein, based on field data from the Danish national database. They reported heritabilities of liability ranging from 0.04 (Staph. aureus) to 0.09 (gram-positive pathogens as a group).

In Norway, mastitis has been included in the breeding program of the Norwegian Red breed since 1978. Genetic evaluation is based on records of veterinary treated CM cases from The Norwegian Dairy Herd Recording System (NDHRS). This is a database containing registrations from the farmers, veterinarians, slaughterhouses, dairies, mastitis laboratories, and the breeding organization in Norway. These records are the basis for genetic evaluation of dairy cattle and give necessary information for herd management and preventive health measures. Data from NDHRS are also used in 
general advising, information, research, statistics, and prognoses. More than $97.5 \%$ of the Norwegian dairy cows are included in the recording system (Tine, 2009). Since 2000, bacteriological milk sample results from the mastitis laboratories have been recorded routinely into the NDHRS. These data may provide valuable information on pathogen-specific clinical mastitis (PSCM). This information has so far not been used in genetic analyses.

The frequency of mastitis pathogens may differ between countries, type of housing (tie-stall or freestall), management systems, milking machine equipment (automatic milking systems or milk liners), and dairy breeds. Staphylococcus aureus is the main mastitis pathogen in Norway (Østerås et al., 2006), whereas Strep. uberis is the most frequent mastitis pathogen in Denmark (Sørensen et al., 2009) and CNS in Finland (Pitkälä et al., 2004). Results are, therefore, not always directly comparable. The Nordic countries are the only countries that collect mastitis pathogen information in national databases. Sweden has registered pathogen information since 1993 (Holmberg et al., 2008), Denmark since 1998 (Sørensen et al., 2009), Norway since 2000, and Finland since 2004 (Koivula et al., 2007).

The objective of this study was to present the first genetic analysis of pathogen data from the Norwegian mastitis laboratories. The specific objectives were to estimate heritabilities of and genetic correlations among unspecific CM (UCM) and CM caused by the 3 most common mastitis pathogens in Norway, and examine whether the ranking of bulls differs between the various PSCM traits.

\section{MATERIALS AND METHODS}

\section{Pathogen Data}

From January 2000 to November 2009 a total of 244,135 milk samples (cow level) were analyzed and registered in the NDHRS. The milk samples were collected and analyzed at quarter level, and during data editing they were matched together. All of the statistical analyses were done at cow level. The bacteriological examination of the milk samples was described by Whist et al. (2007). Approximately 20,000 milk samples were analyzed each year, except in 2003 and 2004, as shown in Figure 1. The larger number of analyzed milk samples these 2 yr was due to a research project by Whist et al. (2007), which also accounts for the larger number of culture negative milk samples during these years, in an otherwise decreasing trend. No pathogens were found in $39.5 \%$ of the milk samples, and $14.3 \%$ of the samples were not possible to analyze due to mixed flora, empty or broken containers, or sour milk at ar- rival to the laboratory. The distribution of pathogens in percentage of positive milk samples per year is shown in Figure 2. The proportion of Staph. aureus-positive milk samples has decreased since 2004, whereas the proportion of CNS-positive samples has increased. Some of these changes are due to an alteration of the classifying system in 2006, which defines more CNS samples as positive compared with earlier. Staphylococcus aureus and CNS were the most frequent pathogens, with 32 and $38 \%$ of the positive samples in 2009 , respectively.

\section{Trait Definitions}

Data on first-lactation Norwegian Red cows, calving from January 2000 through December 2008, were extracted from the NDHRS database The cows were sired by a Norwegian Red AI bull, and were 20 to 36 mo old at first calving.

All CM records from $30 \mathrm{~d}$ before to $300 \mathrm{~d}$ after calving were merged with pathogen information. Only bacteriological milk samples taken within $\pm 7 \mathrm{~d}$ from a CM record were considered. To ensure a certain amount of pathogen information, only herds with at least 1 bacteriological milk sample that could be matched with a CM treatment record were included. In Norway, the average herd size is small (21 cows per herd) and stricter editing was, therefore, difficult. Besides, many herds have no CM treatment during a year. Bacteriological milk samples are not mandatory, and only a small proportion of CM cases could be matched to a milk sample (e.g., a corresponding bacterial milk sample was available for only $7 \%$ of all CM cases in 2009). Therefore, editing is a tradeoff between strict editing and discarding too many records. From the original 851,363 first-lactation cows, 234,088 were included in the analyses. Several different pathogens were identified from the milk samples, but many with frequencies too low to be used for genetic analysis. Staphylococcus aureus, Streptococcus dysgalactiae, and Enterococcus spp. and Escherichia coli were the most frequent pathogens that could be associated with CM. Coagulase-negative staphylococci were not included even though CNS is one of the most common mastitis pathogens, because in Norway, CNS cause mainly subclinical mastitis. Four mastitis traits were defined, 1 for each of the 3 PSCM and 1 for UCM. The UCM trait was defined as a CM record with 1) no milk sample analyzed, 2) milk sample analyzed but no pathogens found, or 3) milk sample analyzed and a pathogen other than the 3 previously mentioned was found. The 4 traits were defined as binary ( 1 or 0$)$, scored as 1 if the cow had at least 1 case of the certain type of CM, 0 otherwise. The overall frequencies of the PSCM traits were low: E. coli, 0.4\%; Staph. aureus, $1.9 \%$; and Strep. dysgalactiae, $0.6 \%$, whereas UCM had 


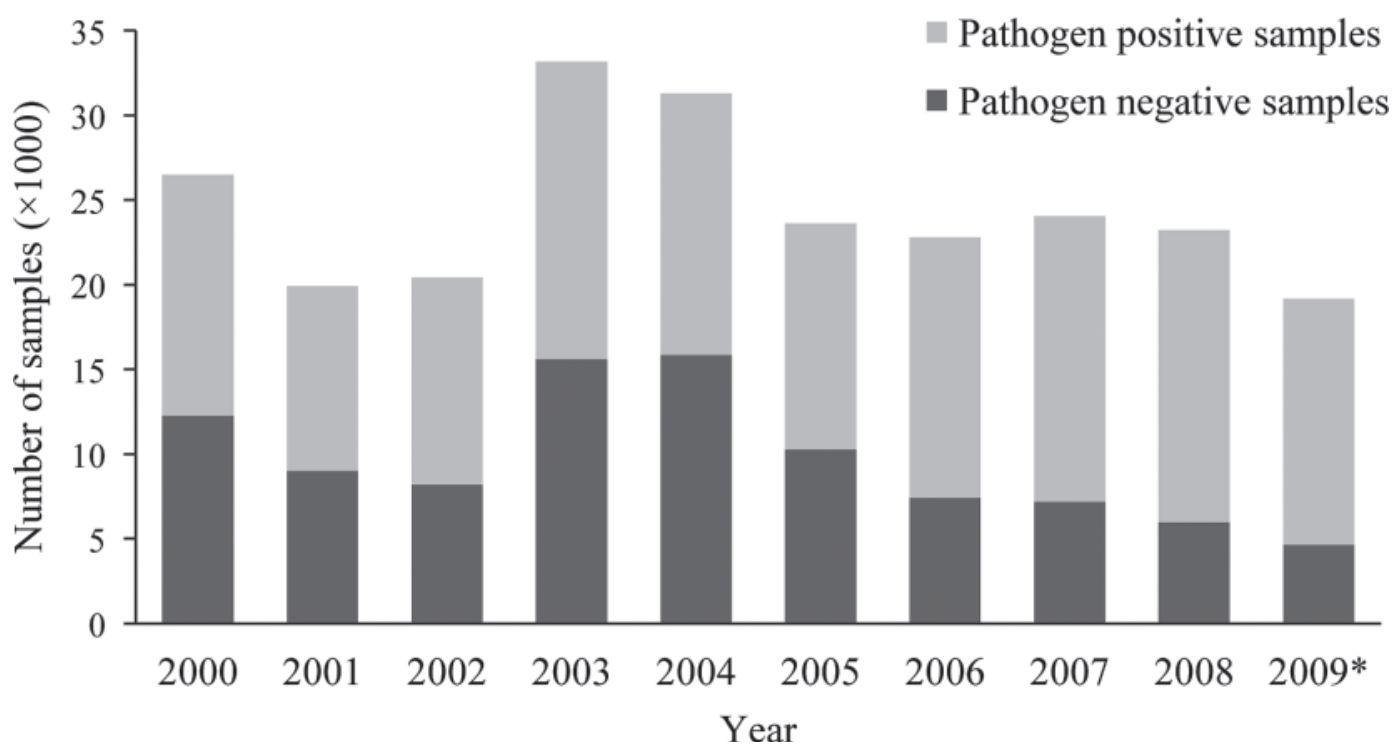

Figure 1. Number of milk samples analyzed at mastitis laboratories per year (cow level). *December is not included.

a frequency of $14.5 \%$. As a cow can be positive for more than 1 pathogen and have more than 1 case of CM during the lactation, the overall mastitis frequency of $16.9 \%$ is lower than the sum of the analyzed traits.
A sire pedigree-file with 3,156 bulls was generated by tracing the sires and maternal grandsires of the 1,565 bulls with daughters in the data set back as far as possible.

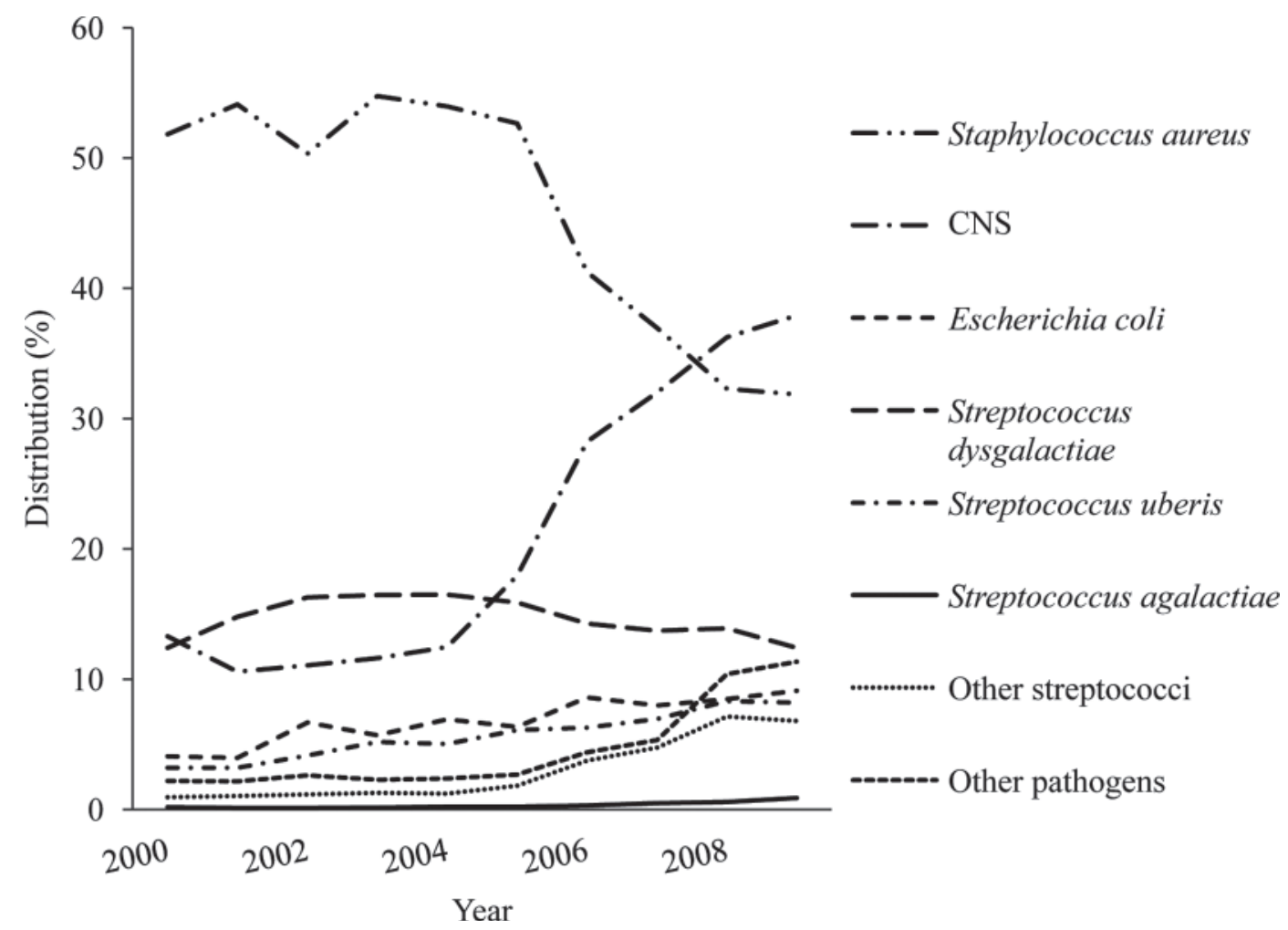

Figure 2. Distribution of pathogens in culture-positive milk samples analyzed at the mastitis laboratories. 
Table 1. Posterior means (SD) for sire $\left(\sigma_{\mathrm{s}}^{2}\right)$ and herd $\left(\sigma_{\mathrm{h} 5 \mathrm{y}}^{2}\right)$ variances, and the corresponding heritability ${ }^{1}\left(\mathrm{~h}^{2}\right)$ with the 95\% highest posterior density (HPD) intervals for unspecific, Staphylococcus aureus, Streptococcus dysgalactiae, and Escherichia coli clinical mastitis

\begin{tabular}{lcccc}
\hline $\begin{array}{l}\text { Clinical } \\
\text { mastitis trait }\end{array}$ & $\left(\sigma_{\mathrm{s}}^{2}\right)$ & $\left(\sigma_{\mathrm{h} 5 \mathrm{y}}^{2}\right)$ & $\mathrm{h}^{2}$ & HPD \\
interval
\end{tabular}

${ }^{1}$ Heritability was computed as $\mathrm{h}^{2}=4 \sigma_{\mathrm{s}}^{2} /\left(\sigma_{\mathrm{s}}^{2}+\sigma_{\mathrm{h} 5 \mathrm{y}}^{2}+1\right)$.

\section{Model}

A Bayesian approach using Gibbs sampling was applied. A 4-variate threshold liability sire model was used to analyze the data. The threshold model (e.g., Gianola and Foulley, 1983) postulates that the probability of response of a binary trait can be measured on an underlying continuous scale of liabilities, which is assumed to be normally distributed. The observed binary response take the value 1 if the liability is above a fixed threshold; otherwise, it takes the value 0 . The threshold and the residual variance were set to 0 and 1 , respectively, as these parameters are not identifiable. In matrix notation, the model can be written as

$$
\lambda=\mathbf{X} \boldsymbol{\beta}+\mathbf{Z}_{\mathbf{h}} \mathbf{h}+\mathbf{Z}_{\mathrm{s}} \mathbf{s}+\mathbf{e},
$$

where $\boldsymbol{\lambda}$ is a vector of unobserved liabilities for the 4 traits, $\boldsymbol{\beta}$ is a vector of systematic effects, including age at first calving (17 classes) and month-year of calving (108 classes), $\mathbf{h}$ is a vector of random herd-5-yr effects $(7,720$ levels $), \mathbf{s}$ is the random effect of sire $(3,156 \mathrm{lev}-$ els), $\mathbf{e}$ is the vector of residual effects, and $\mathbf{X}, \mathbf{Z}_{\mathbf{h}}$, and $\mathbf{Z}_{\mathrm{s}}$ are the corresponding incidence matrices. The age at first calving was from 20 to $36 \mathrm{mo}$ and was defined in single months. Herd-5-yr classes were defined by using 2 time periods of approximately 5 yr (2000-2004 and 2005-2008). The residual correlations involving UCM were set to 0 , as no cows could be categorized as positive both for UCM and for any of the PSCM traits.
The (co)variance components were estimated using the RJMC procedure in the DMU software (Madsen and Jensen, 2007). With the Raftery and Lewis convergence diagnostics method in the Bayesian Output Analysis (BOA) software (Smith, 2003), it was decided to discard the first 5,000 iterations as burn-in, and thereafter use a total chain length of 500,000 iterations. All samples after burn-in were used for posterior inferences.

\section{RESULTS AND DISCUSSION}

\section{Heritabilities}

The posterior means of sire variance, herd-5-yr variance, and heritability of liability for the 4 traits are shown in Table 1. The posterior means of heritability ranged from 0.02 to 0.06 , with standard deviation $\leq 0.01$. Figure 3 shows that the posterior density distributions of the heritabilities were symmetric and reasonably sharp with some overlapping, mainly for the PSCM traits. Unspecific CM had the highest heritability. The results were in agreement with previous studies. Sørensen et al. (2009) analyzed field data from first-lactation Danish Holstein cows and estimated heritabilities of liability of 0.11 for unspecific mastitis (including both clinical and subclinical), 0.04 for Strep. dysgalactiae, 0.05 for E. coli, and 0.04 for Staph. aureus mastitis (SD <0.015). In a Dutch study, de Haas et al. (2002) estimated heritabilities (SE) of $0.05(0.03)$, 0.06 (0.03), and 0.05 (0.02) for Strep. dysgalactiae, E.

Table 2. Posterior means (SD) for genetic (above diagonal) and residual ${ }^{1}$ (below diagonal) correlations between unspecific, Escherichia coli, Staphylococcus aureus, and Streptococcus dysgalactiae clinical mastitis (CM), and their $95 \%$ highest posterior density interval in brackets

\begin{tabular}{lccc}
\hline Clinical & & & \\
mastitis trait & E. coli & Staph. aureus & Strep. dysgalactiae \\
\hline Unspecific & $0.79(0.09)$ & $0.85(0.07)$ & $0.87(0.07)$ \\
E. coli & {$[0.60-0.94]$} & {$[0.72-0.96]$} & {$[0.73-0.96]$} \\
& & $0.80(0.10)$ & $0.75(0.14)$ \\
Staph. aureus & $0.49(0.06)$ & {$[0.60-0.95]$} & {$[0.47-0.94]$} \\
Strep. dysgalactiae & {$[0.43-0.54]$} & & $0.82(0.10)$ \\
& $0.39(0.03)$ & $0.60(0.02)$ & \\
\hline
\end{tabular}

${ }^{1}$ The residual correlations between unspecific $\mathrm{CM}$ and the other traits were set to 0 . 


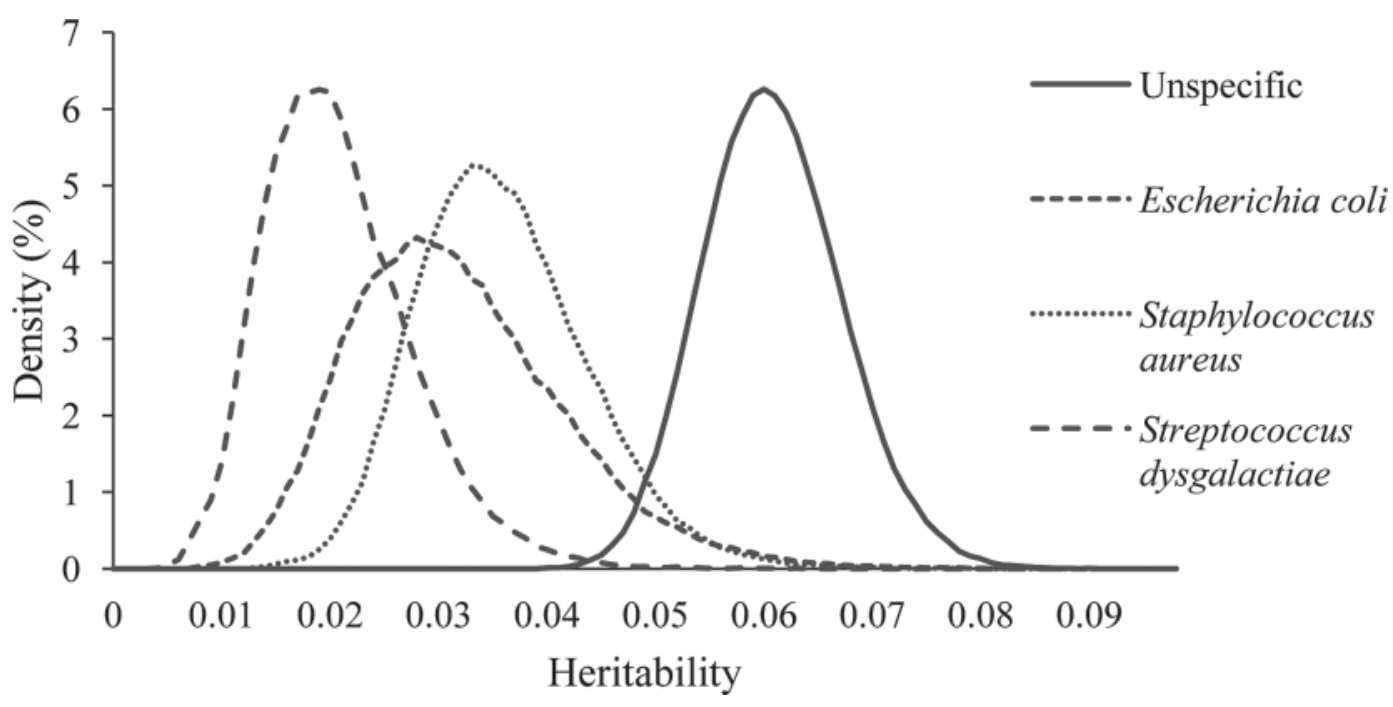

Figure 3. The posterior density distributions of heritability of liability to unspecific, Escherichia coli, Staphylococcus aureus, and Streptococcus dysgalactiae clinical mastitis.

coli, and Staph. aureus mastitis, respectively, and 0.04 (0.01) for overall CM. Schafberg et al. (2006) reported heritabilities (SE) of 0.09 (0.05) and 0.07 (0.05) for IMI caused by CNS and Staph. aureus, respectively, and 0.06 (0.03) for any IMI.

\section{Genetic and Residual Correlations}

The posterior means of genetic and residual correlations are shown in Table 2. Although all the posterior distributions of genetic correlations were skewed and with long tails to the left (Figures 4 and 5), the results suggest strong and positive genetic correlations among the 4 traits, with posterior means (SD) ranging from 0.75 (0.14) to 0.87 (0.07). As the correlations were lower than 1, the 3 PSCM traits can be considered highly correlated but not exactly the same. The genetic correlations among the PSCM traits were higher than those found by Sørensen et al. (2009), who reported genetic correlations ranging from 0.45 to 0.77 . In the current study, the highest genetic correlations were found between UCM and Staph. aureus (0.85) and UCM and Strep. dysgalactiae (0.87), whereas the lowest were found between $E$. coli and the other traits (0.75-0.80). Different bacteria elicit different immune responses (Bannerman et al., 2004; Oviedo-Boyso et al., 2007) and if these immune responses have somewhat different genetic backgrounds, genetic differences in susceptibility to pathogens may be expected. As only a limited number of cows were tested for pathogens, many non-classified cases of PSCM exist in the UCM group and high correlations can, therefore, be expected. It is reasonable to believe that with more pathogen information, more precise genetic correlations between the PSCM traits could be estimated in Norwegian Red.
The residual correlations were moderate, ranging from 0.39 (Strep. dysgalactiae and E. coli) to 0.60 (Strep. dysgalactiae and Staph. aureus). This indicates correlations between the PSCM traits that are not explained by sire- or herd-5-yr correlations.

\section{Sire Ranking}

Rank correlations between sire posterior means for the 4 traits were high, ranging from 0.95 to 0.98 (Table 3 ). Among the 10 highest-ranking bulls for UCM, some re-ranking was observed, and only 3 bulls were among the top 10 for all 4 traits (Table 4). Sire 4 for UCM was not in the top 10 for any of the PSCM traits, whereas sire 5 for UCM was number 1 for $E$. coli $\mathrm{CM}$ and number 3 for both Staph. aureus and Strep. dysgalactiae CM. The re-ranking shown here is not large enough to have a practical impact on the overall breeding values of the bulls. However, this may change with more pathogen information. Norwegian dairy farmers and veterinarians are encouraged to collect more milk samples for pathogen analysis from cows with CM to improve the pathogen information in the population.

Table 3. Spearman rank correlations of the sire posterior mean for unspecific, Escherichia coli, Staphylococcus aureus, and Streptococcus dysgalactiae clinical mastitis

\begin{tabular}{lccc}
\hline $\begin{array}{l}\text { Clinical } \\
\text { mastitis trait }\end{array}$ & Unspecific & E. coli & $\begin{array}{l}\text { Staph. } \\
\text { aureus }\end{array}$ \\
\hline E. coli & 0.95 & & \\
Staph. aureus & 0.95 & 0.95 & \\
Strep. dysgalactiae & 0.98 & 0.97 & 0.96 \\
\hline
\end{tabular}




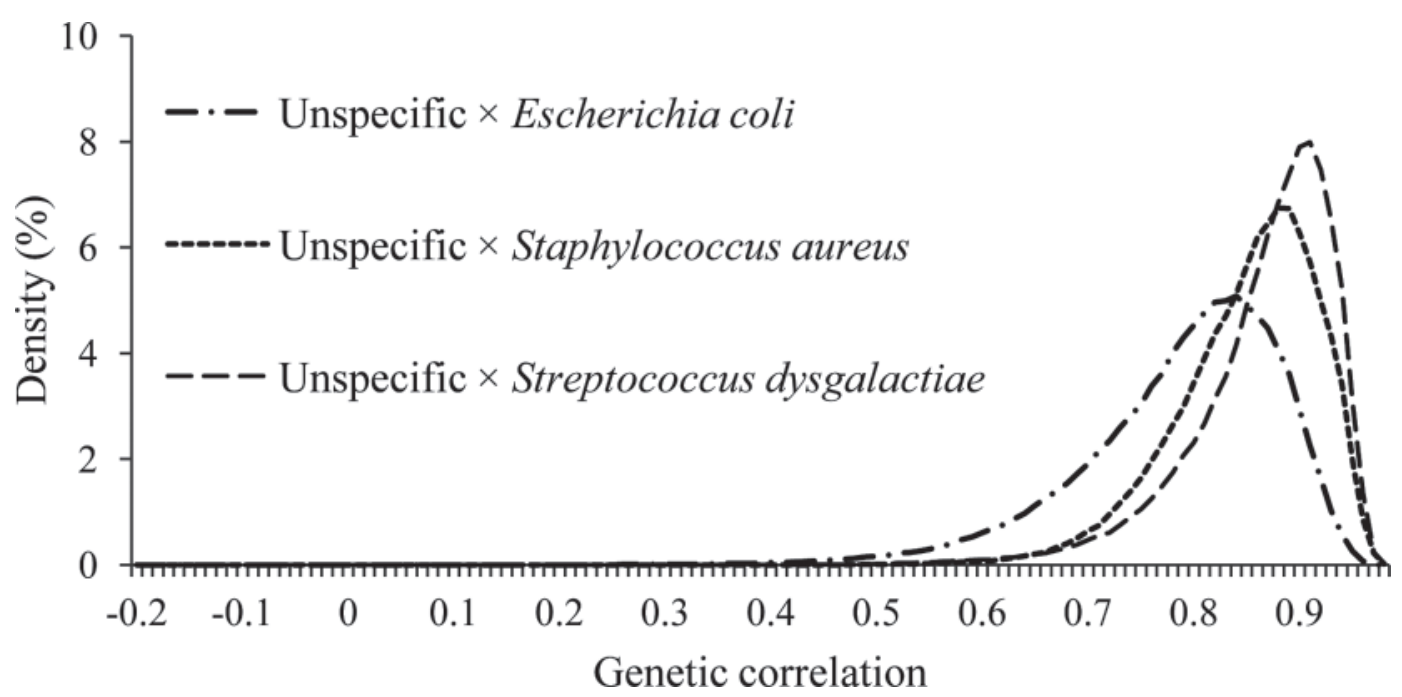

Figure 4. The posterior density distributions of the genetic correlations between unspecific clinical mastitis and Escherichia coli, Staphylococcus aureus, and Streptococcus dysgalactiae clinical mastitis.

\section{Challenges and Limitations}

Data from the mastitis laboratories is an additional source of data that may provide valuable information on PSCM. However, some challenges and limitations are attached to using these data in genetic evaluations. Sending milk samples to the mastitis laboratories for pathogen analyses is not mandatory, and currently the proportion of $\mathrm{CM}$ cases with pathogen information is too low to be used in routine evaluations. Challenges existed with respect to data editing and trait definitions. Pathogens can be present in a milk sample even though no clinical disease exists. Therefore, pathogen data from the mastitis laboratory were linked with records of veterinary treatments of $\mathrm{CM}$, and only pathogen records that were confirmed to be from a CM case were included. Here, pathogen information was available only for some of the mastitis cases, and also mastitis can occur even though no pathogens are present in the milk samples. We aimed to take this into account by defining UCM and analyzing this trait multivariate together with the PSCM traits.

\section{CONCLUSIONS}

Genetic correlations among the CM traits were positive and strong, but lower than 1. Some re-ranking of sires was observed between the different CM traits.

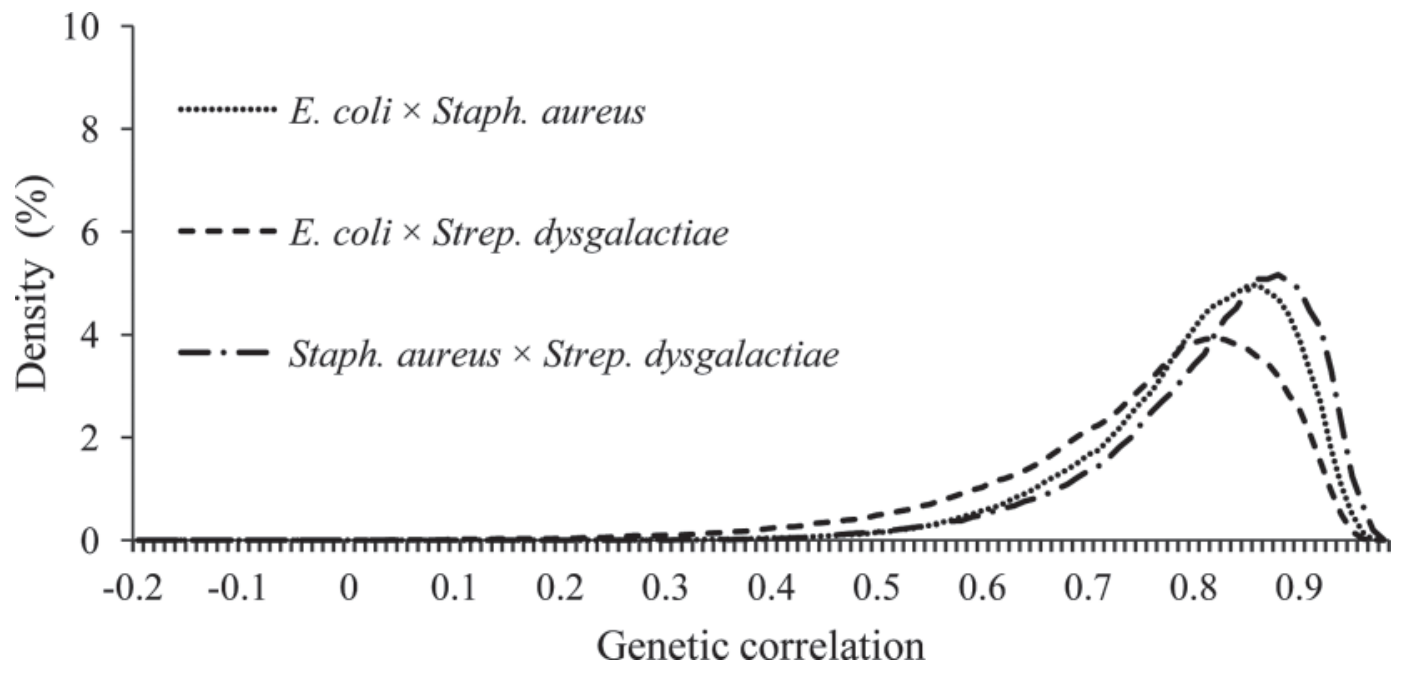

Figure 5. The posterior density distributions of the genetic correlations between Escherichia coli, Staphylococcus aureus, and Streptococcus dysgalactiae clinical mastitis. 
Table 4. The 10 highest-ranking bulls for unspecific clinical mastitis (UCM), and their ranking for Staphylococcus aureus, Streptococcus dysgalactiae, and Escherichia coli clinical mastitis (CM)

\begin{tabular}{lccc}
\hline & \multicolumn{3}{c}{ Rank based on sire posterior means for } \\
\cline { 2 - 4 } UCM & E. coli CM & Staph. aureus CM & Strep. dysgalactiae CM \\
\hline 1 & 5 & 15 & 5 \\
2 & 6 & 5 & 1 \\
3 & 15 & 14 & 2 \\
4 & 14 & 32 & 3 \\
5 & 1 & 3 & 10 \\
6 & 2 & 2 & 15 \\
7 & 3 & 10 & 13 \\
9 & 9 & 12 & 9 \\
10 & 7 & 1 & 4
\end{tabular}

This indicates that these traits, to some extent, can be considered as different, and that pathogen data may provide additional information regarding estimated breeding values of bulls. However, the pathogen information in the Norwegian Red population is at this point too sparse to be used in routine genetic evaluation.

\section{ACKNOWLEDGMENTS}

The authors thank the Norwegian Dairy Herd Recording System and the Norwegian Cattle Health service (Ås, Norway) for access to data.

\section{REFERENCES}

Bannerman, D. D., M. J. Paape, J.-W. Lee, X. Zhao, J. C. Hope, and P. Rainard. 2004. Escherichia coli and Staphylococcus aureus elicit differential innate immune responses following intramammary infection. Clin. Diagn. Lab. Immunol. 11:463-472.

Barkema, H. W., Y. H. Schukken, and R. N. Zadoks. 2006. Invited review: The role of cow, pathogen, and treatment regimen in the therapeutic success of bovine Staphylococcus aureus mastitis. J. Dairy Sci. 89:1877-1895.

Calvinho, L. F., R. A. Almeida, and S. P. Oliver. 1998. Potential virulence factors of Streptococcus dysgalactiae associated with bovine mastitis. Vet. Microbiol. 61:93-110.

de Haas, Y., H. W. Barkema, and R. F. Veerkamp. 2002. Genetic parameters of pathogen-specific incidence of clinical mastitis in dairy cows. Anim. Sci. 74:233-242.

Gianola, D., and J. L. Foulley. 1983. Sire evaluation for ordered categorical data with a threshold model. Genet. Sel. Evol. 15:201-224.

Gröhn, Y. T., D. J. Wilson, R. N. González, J. A. Hertl, H. Schulte, G. Bennet, and Y. H. Schukken. 2004. Effect of pathogen-specific clinical mastitis on milk yield on dairy cows. J. Dairy Sci. $87: 3358-3374$.

Holmberg, M., W. F. Fikse, L. Andersson-Eklund, K. Artursson, and A. Lundén. 2008. Genetic analysis of pathogen-specific mastitis. Page 82 in Book of Abstracts of the 59th Annual Meeting of the European Association for Animal Production. Wageningen Academic Publishers, Wageningen, the Netherlands.

Koivula, M., A. Pitkälä, S. Pyörälä, and E. A. Mäntysaari. 2007. Distribution of bacteria and seasonal and regional effects in a new database for mastitis pathogens in Finland. Acta Agric. Scand. A $57: 89-96$.
Madsen, P., and J. Jensen. 2007. An User's Guide to DMU. A Package for Analyzing Multivariate Mixed Models. University of Aarhus, Research Center, Foulum, Tjele, Denmark.

Nash, D. L., G. W. Rogers, J. B. Cooper, G. L. Hargrove, J. F. Keown, and L. B. Hansen. 2000. Heritability of clinical mastitis incidence and relationship with sire transmitting abilities for somatic cell score, udder type traits, productive life, and protein yield. J. Dairy Sci. 83:2350-2360.

Østerås, O., L. Sølverød, and O. Reksen. 2006. Milk culture results in a large Norwegian survey_Effects of season, parity, days in milk, resistance, and clustering. J. Dairy Sci. 89:1010-1023.

Oviedo-Boyso, J., J. J. Valdez-Alarcón, M. Cajero-Juárez, A. OchoaZarzosa, J. E. López-Meza, A. Bravo-Patiño, and V. M. Baizabal-Aguirre. 2007. Innate immune responses of bovine mammary gland to pathogenic bacteria responsible for mastitis. J. Infect. 54:399-409.

Piepers, S., K. Peeters, G. Opsomer, H. W. Barkema, K. Frankena, and S. De Vliegher. 2011. Pathogen group specific risk factors at herd, heifer and quarter levels for intramammary infections in early lactating dairy heifers. Prev. Vet. Med. 99:91-101.

Pitkälä, A., M. Haveri, S. Pyörälä, V. Myllys, and T. Honkanen-Buzalski. 2004. Bovine mastitis in Finland 2001-Prevalence, distribution of bacteria, and antimicrobial resistance. J. Dairy Sci. $87: 2433-2441$.

Reksen, O., L. Sølverød, A. J. Branscum, and O. Østerås. 2006. Relationship between milk culture results and treatment for clinical mastitis or culling in Norwegian dairy cattle. J. Dairy Sci. 89:2928-2937.

Schafberg, R., F. Rosner, and H. H. Swalve. 2006. Examinations on intramammary infections in dairy cows based on pathogen-specific data. Communication 15-13 in Proceedings of the 8th World Congress on Genetics Applied to Livestock Production, Belo Horizonte, Brazil.

Smith, B. J. 2003. Bayesian Output Analysis Program (BOA) Version 1.0 User's Manual.

Sørensen, L. P., P. Madsen, T. Mark, and M. S. Lund. 2009. Genetic parameters for pathogen-specific mastitis resistance in Danish Holstein cattle. Animal 3:647-656.

Tine. 2009. Tine Rådgiving statistikksamling 2009. (In Norwegian with English table headings.) Accessed May 5, 2011. http:// medlem.tine.no/tp/page?id=647.

Weller, J. I., A. Saran, and Y. Zeliger. 1992. Genetic and environmental relationships among somatic cell count, bacterial infection, and clinical mastitis. J. Dairy Sci. 75:2532-2540.

Whist, A. C., O. Østerås, and L. Sølverød. 2007. Staphylococcus aureus and Streptococcus dysgalactiae in Norwegian herds after introduction of selective dry cow therapy and teat dipping. J. Dairy Res. $74: 1-8$. 